\title{
Dårligere vaksine mot humant papillomvirus
}

\author{
Folkehelseinstituttet har nylig besluttet å vaksinere unge jenter med en annen vaksinetype mot humant \\ papillomvirus enn den som til nå er brukt. Beslutningen er lite gjennomtenkt og vil gi norske kvinner et \\ dårligere helsetilbud enn de har hatt.
}

Siden 2009 har jenter i 7. klasse fått tilbud om vaksine mot humant papillomvirus (HPV). Den vaksinen man til nå har brukt (Gardasil), beskytter mot fire virusstammer. Det er de onkogene HPV-16 og HPV-18, i tillegg til HPV-6 og HPV-11, som forårsaker $>90 \%$ av alle tilfeller av kjønnsvorter (1). Gardasil er nå blitt videreutviklet til Gardasil 9, som inneholder proteiner fra ytterligere fem kreftfremkallende HPVtyper (2).

Nå har imidlertid Folkehelseinstituttet innstilt Cervarix som nasjonal HPV-vaksine fra høsten 2017 (3). Dette er i tråd med tilbudet om gratis Cervarix-vaksine i perioden 2016-18 for kvinner født 1991 og senere som ikke har fått Gardasil (4).

Cervarix beskytter bare mot HPV-16 og HPV-18. Grunnen til at Folkehelseinstituttet har valgt denne, er at den har vist god beskyttende effekt mot forstadier til livmorhalskreft uavhengig av type humant papillomvirus (kryssbeskyttelse). Instituttet vurderer derfor de to vaksinene til å ha jevngod beskyttelse mot livmorhalskreft totalt sett (3).

Dette er tvilsomt, siden den kryssbeskyttende effekten av Cervarix må forventes å ha kort varighet og at den direkte effekten som Gardasil 9 har mot de andre fem onkogene virusstammene mangler $(5,6)$. Med Gardasil 9 kan man forvente å få en $90 \%$ reduksjon av livmorhalskreft (2), med mulig stor innsparing fra dagens livmorhalsscreeningprogram (7). Det er usikkert om Cervarix vil få like god effekt på lang sikt.

Men like betenkelig er det at Folkehelseinstituttet helt har sett bort fra at Gardasil 9 dessuten beskytter mot HPV-6 og HPV-11, som forårsaker $>90 \%$ av alle tilfeller av kjønnsvorter. Kjønnsvorter rammer om lag $10 \%$ av den seksuelt aktive befolkningen i løpet av livet (8). Dette er ingen livstruende infeksjon, men den forekommer hyppig, er kostnadskrevende for helsevesenet og kan være svært belastende for livskvali- teten. En pasient skrev en gang følgende til meg: «Kjønnsvortene har endret livet mitt og ødelagt forhold og store deler av privatlivet mitt. Jeg føler meg ikke lenger som et

\section{«Det er trist for pasien- tene og kostnadskre- vende for helsevesenet i Norge hvis beslutnin- gen om à ta i bruk den tovalente HPV-vaksinen står ved lag»}

normalt menneske. Dette er den «vanligste sykdommen» i verden, men det endrer ikke stigmaet som følger med og at jeg kan gi noen andre en sykdom de heller ikke blir kvitt.»

I Australia startet man allerede i 2007 med den firevalente HPV-vaksinen til 12 år gamle jenter. De første to årene ble i tillegg alle kvinner opp til 26 år tilbudt vaksine. Hos jenter under 21 år i Australia er kjønnsvorter nå nesten utryddet (9), og man har sett en betydelig reduksjon også blant unge menn som har sex med kvinner. De blir ikke lenger smittet av sine partnere. Denne nedgangen har man ikke sett hos menn som har sex med menn.

Det er trist for pasientene og kostnadskrevende for helsevesenet i Norge hvis beslutningen om å ta i bruk den tovalente HPVvaksinen står ved lag.

Pasienten som er omtalt i artikkelen, har gitt sitt samtykke til at sitatet publiseres.

\section{Harald Moi}

harald.moi@medisin.uio.no
Harald Moi (f. 1942) er spesialist i hud- og veneriske sykdommer, overlege ved Olafiaklinikken, Oslo universitetssykehus, og professor emeritus ved Universitetet i Oslo.

Forfatter har fylt ut ICMJE-skjemaet og oppgir følgende interessekonflikter: Han har vært lokal forskningsleder for HPV-vaksinestudier for MSD, det gjelder både den firevalente og den nivalente vaksinen. Han har ikke mottatt honorar for dette arbeidet, som er blitt administrert gjennom inven2 ved Oslo universitetssykehus.

\section{Litteratur}

1. Brown DR, Schroeder JM, Bryan JT et al. Detection of multiple human papillomavirus types in Condylomata acuminata lesions from otherwise healthy and immunosuppressed patients. J Clin Microbiol 1999; 37: 3316-22.

2. Joura EA, Giuliano AR, Iversen OE et al. A 9-valent HPV vaccine against infection and intraepithelial neoplasia in women. N Engl J Med 2015; 372: $711-23$.

3. Folkehelseinstituttet. Endring av HPV-vaksine i barnevaksinasjonsprogrammet. https://www.fhi.no/ nyheter/2017/endring-av-hpv-vaksine/ (5.4.2017).

4. Folkehelseinstituttet. Leverandør av HPV-vaksine er valgt etter åpen anbudskonkurranse. https://www. fhi.no/nyheter/2016/leverandor-av-hpv-vaksine-ervalgt-etter-apen-anbudskonkurranse/ (5.4.2017).

5. Malagón T, Drolet M, Boily MC et al. Cross-protective efficacy of two human papillomavirus vaccines: a systematic review and meta-analysis. Lancet Infect Dis 2012; 12: 781 -9.

6. Mesher D, Panwar K, Thomas SL et al. Continuing reductions in HPV 16/18 in a population with high coverage of bivalent HPV vaccination in England: an ongoing cross-sectional study. BMJ Open 2016 6: e009915.

7. Iversen OE. HPV-vaksinen ti år - hva er status? Tidsskr Nor Legeforen 2017; 137: 430-1.

8. Kjær SK, Tran TN, Sparen P et al. The burden of genital warts: a study of nearly 70,000 women from the general female population in the 4 Nordic countries. J Infect Dis 2007; 196: 1447-54.

9. Chow EP, Read TR, Wigan R et al. Ongoing decline in genital warts among young heterosexuals 7 years after the Australian human papillomavirus (HPV) vaccination programme. Sex Transm Infect 2015; 91: 214-9.

Mottatt 30.3. 2017, første revisjon innsendt 5.4. 2017, godkjent 18.4. 2017. Redaktør: Ketil Slagstad.

Publisert først på nett. 